\title{
Introduction to Professor Anghie
}

\author{
Catherine Hawkins
}

Good afternoon. I'd like to acknowledge the traditional owners of the land on which we meet, and pay my respects to their elders, past, present and emerging.

I acknowledge Deborah's family: her parents, Moss and Shirley, her brother Daniel, Gerry, her cousin Gina and her lovely daughters, Hannah and my fairy goddaughter Rosa.

I'd like to thank Kim, Hilary and all the organisers for putting this day together.

We are very lucky to have Professor Tony Anghie here to talk to us this afternoon all the way from the University of Utah. Tony crossed paths with Deborah way back in the days of the Nauru Commission of Inquiry. Their high-flying paths crossed again later in Harvard and other esteemed locales.

Tony has had a distinguished career. He has scored an academic Daily Double, to use a racing term. He has been honoured by his university both as Outstanding Teacher of the Year and Outstanding Scholar of the Year. In a room of academics that will resonate as a particularly impressive double act.

One usually starts such sessions noting that it is a pleasure to be here. But today that is not so much the case for me. Today is not at all an unequivocal pleasure. 
In reading Deborah Cass's piece on rethinking self-determination in preparation to chair this session, all I wanted to do was engage in a spirited discussion with her about her piece and the ideas in it. I've been picturing that spirited conversation with Deborah nestled in a comfy, sunny corner of her beach house in Somers.

But, of course, that is not to be.

So. This is a tough day to engage with the divides Deborah traversed without having her here to debate them with us.

I must say that when Kim and Hilary mentioned the plans for today, I did wonder whether Deborah would have been aghast at the very idea of today's symposium. I can hear Deborah modestly telling us with a slightly dismissive shake of her head and her hand that her academic legal work was really nothing special and there were plenty of other people who were doing more significant work.

But Deborah did significant academic legal work in her public sphere days, and I am glad that we're here today to remember that aspect of her life.

I met Deborah as she was on the up in her career as a scholar. I had come to Canberra in 1993 to take up a graduate role in Attorney-General's Department. In 1993 she had of course just been awarded her Caltex scholarship. It was around then that I had the amazing good fortune to meet Deborah. And where did I meet her? Over the back fence in Nimbin Street, Narrabundah, where we both lived.

Throughout the late 1980s and early 90s at university I had been boring senseless all my family and many extended friends with my constant undergrad barrages about structural inequality in our society.

So. I could not believe my good luck when I met Deborah over the back fence. Being from Sydney, and therefore not as familiar with the Melbourne core of the Cass clan, my first overexcited question to Deborah was whether she was related to Bettina. I'd been imbibing Bettina Cass's work for feminist papers I'd written at uni. 'Get out. You're her niece?' And so our friendship began.

How lucky was I to meet a friend like Deborah. Someone with whom I could seamlessly move from Catharine McKinnon and Andrea Dworkin's work through to discussing, almost as energetically, important matters of fashion, arts and literature. Thank you, Nimbin Street, Narrabundah. 
For me, Deborah's crowning achievements were not her public sphere academic works, important though they were.

For me, Deborah's crowning achievements were her friendship - one that I continue to treasure - and the gorgeous girls she brought in to this world: Hannah and my fairy goddaughter, Rosa.

So, personal reflections aside, let's get stuck in to the topic of this session: Deborah Cass's research contribution to Nauru and beyond. To self-determination.

The concept is of course complex and contested. But given the spoils of statehood: use of force, taxing and spending, shaping society for good and ill (and hopefully for more good than ill), it is no surprise that in the hallowed arena of international law, the concept of self-determination who gets to be a state - is such a contested arena.

Deborah's paper asks whether the 'penumbra of uncertainty' surrounding the concept of self-determination is so pronounced that it obscures the term's settled meaning.

I'm not so convinced. But I'm no scholar. And the fact that Deborah was made me love our conversations all the more. My starting point is my position as a lawyer in the executive government. I work on international crime cooperation, where in international work we deal with grey concepts on a daily basis, but things work out. Yes, there is grey, but it works.

Maybe I'm too used to dealing in pragmatic outcomes. At the negotiations on the new Sustainable Development Goals - which will replace the Millennium Development Goals at Leaders Week in the UN New York in September 2015 - it was the wording on self-determination that was still being negotiated right down to the wire in an exceedingly long document, with 17 goals and 169 targets.

The enduring debate about the scope of self-determination shows us that Deborah was of course right in her focus on drilling in to this important concept, and to exhort us to make it make more sense.

So, Professor, please take the conch from me and share with us your thoughts on Deborah Cass's work on Nauru and beyond. 
This text is taken from Traversing the Divide: Honouring Deborah Cass's Contributions to Public and International Law, edited by Kim Rubenstein, published 2021 by ANU Press, The Australian National University,

Canberra, Australia.

doi.org/10.22459/TD.2021.03 